\title{
Impact of point-of-care screening for hypertension, diabetes and progression of chronic kidney disease in rural Manitoba Indigenous communities
}

\author{
Oksana Harasemiw MSc, Thomas Ferguson MSc, Barry Lavallee MD, Lorraine McLeod RN, Caroline Chartrand RN, \\ Claudio Rigatto MD, Navdeep Tangri MD, Allison Dart MD, Paul Komenda MD
}

Cite as: CMAJ 2021 July 19;193:E1076-84. doi: 10.1503/cmaj.201731

\begin{abstract}
BACKGROUND: In 2013-2015, we conducted point-of-care screening for hypertension, diabetes and chronic kidney disease in rural and remote Indigenous communities in Manitoba, Canada. In this study, we aimed to determine whether optimal follow-up care was provided, defined as proportion of individuals with appropriate kidney disease laboratory testing, medication prescriptions and physician visits.
\end{abstract}

METHODS: We linked screening data from participants to provincial administrative data sets to evaluate whether frequencies of laboratory testing, prescriptions of disease-modifying medications, and primary care and nephrology visits differed in the 18 months before and after screening. We also conducted a propensity score matching analysis to compare outcomes between screened and unscreened adults.

RESULTS: Of 1353 adults who received the screening intervention and who had complete administrative data available, $44 \%$ were at risk of kidney failure at screening. Among these individuals, frequencies of comprehensive laboratory testing (estimated glomerular filtration rate and urine albumin to creatinine ratio) improved by $17.0 \%$ (95\% confidence interval $[\mathrm{Cl}] 11.5$ to 22.5 ), antihyperglycemic medications improved by $4.4 \%$ ( $95 \% \mathrm{Cl} 1.0$ to 7.8$)$, and nephrol- ogy visits for participants meeting referral criteria improved by $5.9 \%(95 \% \mathrm{Cl} 3.4$ to 8.5 ). We observed significant improvements in laboratory testing, antihyperglycemic medications and nephrology visits in the screened group compared with the 1:1 matched comparison group.

INTERPRETATION: Point-of-care screening programs in rural and remote Indigenous communities are adaptable methods for increasing awareness, monitoring risk and treating chronic diseases. Interventions such as the development of a national screening program could improve chronic disease care in high-risk populations.
I

ndigenous people living in rural and remote communities in Canada are often faced with poor clinical and patient-oriented outcomes, in particular higher rates of chronic kidney disease, ${ }^{1,2}$ and its antecedent risk factors of diabetes ${ }^{3}$ and hypertension. ${ }^{4}$ They are also at a higher risk of kidney failure requiring dialysis at a younger age,,$^{5-8}$ and are often required to relocate to urban communities for dialysis, which may negatively affect quality of life. ${ }^{9}$ Although progression of chronic kidney disease to kidney failure can be delayed or prevented with earlier optimization of lifestyle risk factors ${ }^{10,11}$ and targeted pharmacologic interventions, ${ }^{12-14}$ timely identification and stratification based on risk of progressing to kidney failure is necessary. Barriers to care such as poverty and poor access to services, which are related to intergenerational exposure to systemic racism, are salient in rural and remote Indigenous communities and contribute to people often presenting late in their disease course, reducing the time available for preventive interventions.

Targeted screening programs using point-of-care testing equipment directed toward high-risk populations with diabetes and high blood pressure, or populations known to progress rapidly or who have limited access to primary health care, have been shown to be cost-effective methods for identifying and triaging patients to best align resources and treatment pathways with risk of progression. ${ }^{15-17}$ A program evaluation of a point-of-care testing program in Australia (the Quality Assurance for Aboriginal \& Torres Strait Islander Medical Services) found that in the 2 years after the introduction of the program, there was an increase in monitoring 
of hemoglobin $\mathrm{A}_{1 \mathrm{c}}\left(\mathrm{HbA}_{1 \mathrm{c}}\right)$ and urine albumin to creatinine ratio (UACR) levels, and individuals became more aware of their risk and more compliant with monitoring of their risk factors. ${ }^{18}$

The First Nations Community-Based Screening to Improve Kidney Health and Prevent Dialysis (FINISHED) initiative was an Indigenous-led, multidisciplinary mobile point-of-care screening program for chronic kidney disease, diabetes and hypertension, in rural (accessible by road) and remote (accessible by flying-in or by ice roads in winter) Indigenous communities in Manitoba. ${ }^{19}$ The program was designed and executed in close collaboration with Indigenous leaders and organizations. ${ }^{19}$ Previous studies presenting cross-sectional results from FINISHED showed a greater than twofold higher prevalence of chronic kidney disease in people screened compared with the general Canadian population, with prevalence rates of chronic kidney disease and risk factors highest in remote communities..$^{20,21}$ However, the impact of the one-time screening program on ongoing surveillance of individuals who participated and how participants' health service utilization patterns compare with those of individuals living in unscreened communities remains unknown. We aimed to estimate the frequencies of appropriate follow-up laboratory testing, medication prescriptions and physician visits within the 18 months after screening, by linking the FINISHED database to provincial administrative databases.

\section{Methods}

\section{Study design and data sources}

Using personal health identification numbers, we linked the FINISHED screening database with 5 provincial administrative health databases (Appendix 1, Supplementary Table 1, available at www.cmaj.ca/lookup/doi/10.1503/cmaj.201731/tab-related -content) housed within the Population Health Research Data Repository at the Manitoba Centre for Health Policy. ${ }^{22}$ Although health care services for individuals registered under the Indian Act of Canada living on reserves and traditional territories are predominantly funded by federal programs, the Manitoba government funds hospital and physician services in the province, and clinical visits are therefore captured in the provincial administrative databases. Also captured are laboratory tests from publicly funded laboratories, as well as all drug prescriptions.

Participants consented to having their screening data linked with administrative health databases. Additionally, we also received Band Council Resolutions for the linkage from the Regional Health Authority, and the Health Services of the Tribal Councils where screening occurred. Indigenous research principles of Ownership, Control, Access and Possession have been followed throughout this project.

\section{Intervention group}

Our study population included the adults screened as part of the FINISHED initiative between Mar. 11, 2013, and Mar. 26, 2015, who had administrative data available for the 18 months immediately before and after screening. The FINISHED screening program partnered with 2 Tribal Councils to recruit individuals from all of their communities (9 rural and 4 remote). In each of the communities, townhall meetings were conducted to raise initial awareness of the screening program and to provide community members with an opportunity to ask questions and provide feedback. Before the screening sessions, door hangers were hand-delivered to each home with screening time and location information, and advertising campaigns were launched on provincial and local radio stations.

During each screening session, clinical teams collected demographic information, as well as one $0.1 \mathrm{~mL}$ droplet of blood that was analyzed for blood chemistry using the Piccolo Xpress (Abaxis). An additional finger-prick droplet was taken for analysis of $\mathrm{HbA}_{1 \mathrm{c}}$, and a urine sample for UACR. Both samples were analyzed using the DCA Vantage Analyzer (Siemens). A mean of 6 blood pressure measurements were taken using the BpTRU Medical Device. Screeners conducted a comprehensive quality assurance process on the point-ofcare testing equipment to ensure precision and accuracy and calibrated it to a mainframe laboratory. Screeners conducted the internal quality assurance process daily using human serum samples with predefined performance limits; this was monitored by an external reference method laboratory (Canadian External Quality Assurance Laboratory, Vancouver, BC).

Screeners entered all data into a customized iPad app that calculated participants' 5-year risk of kidney failure. ${ }^{19}$ Participants received their results in real time during a risk-based counselling session. The program operated on the basis of a "closed loop" system of care, aiming to ensure risk-appropriate follow-up care was provided; each participant's results were sent to their primary care provider with specific treatment recommendations for ongoing surveillance, and intermediate- and high-risk individuals were referred to a nephrologist. Additionally, participants without a dedicated primary care physician were referred to the primary care team or nursing station located within their community for continued follow-up.

\section{Kidney failure risk}

At the time of their point-of-care screening assessment, participants were classified into categories that reflected their risk of progressing to kidney failure within the next 5 years (no risk, low risk, intermediate risk or high risk) using our risk paradigm (Figure 1), which incorporated the Kidney Failure Risk Equation ${ }^{23,24}$ and other clinically relevant risk factors. For the current analyses, we dichotomized the groups into no risk and some risk (low, intermediate, or high risk), owing to small cell sizes for some of the outcome measures.

\section{Outcomes}

Outcomes analyzed include the following outpatient laboratory tests: UACR or urine protein to creatinine ratio (UPCR), estimated glomerular filtration rate (eGFR) and $\mathrm{HbA}_{1 \mathrm{c}}$ in people with diabetes, within the 18 months before the date of screening ("the index date"), versus within the 18 months after the date of screening. We also evaluated the composite outcome of 1 or more UACR or UPCR test and 1 or more eGFR test in the pre- and postscreening periods.

We evaluated use of the following disease-modifying medications: statins, angiotensin-converting enzyme (ACE) inhibitors or angiotensin II receptor blockers (ARBs) (for individuals with a UACR $\geq 3 \mathrm{mg} / \mathrm{mmol}$, or diabetes), any other antihypertensive medications, and antihyperglycemic medications (in individuals with diabetes). All medications were classified according to the Anatomical Therapeutic Chemical system (Appendix 1, Supplementary Table 2). 


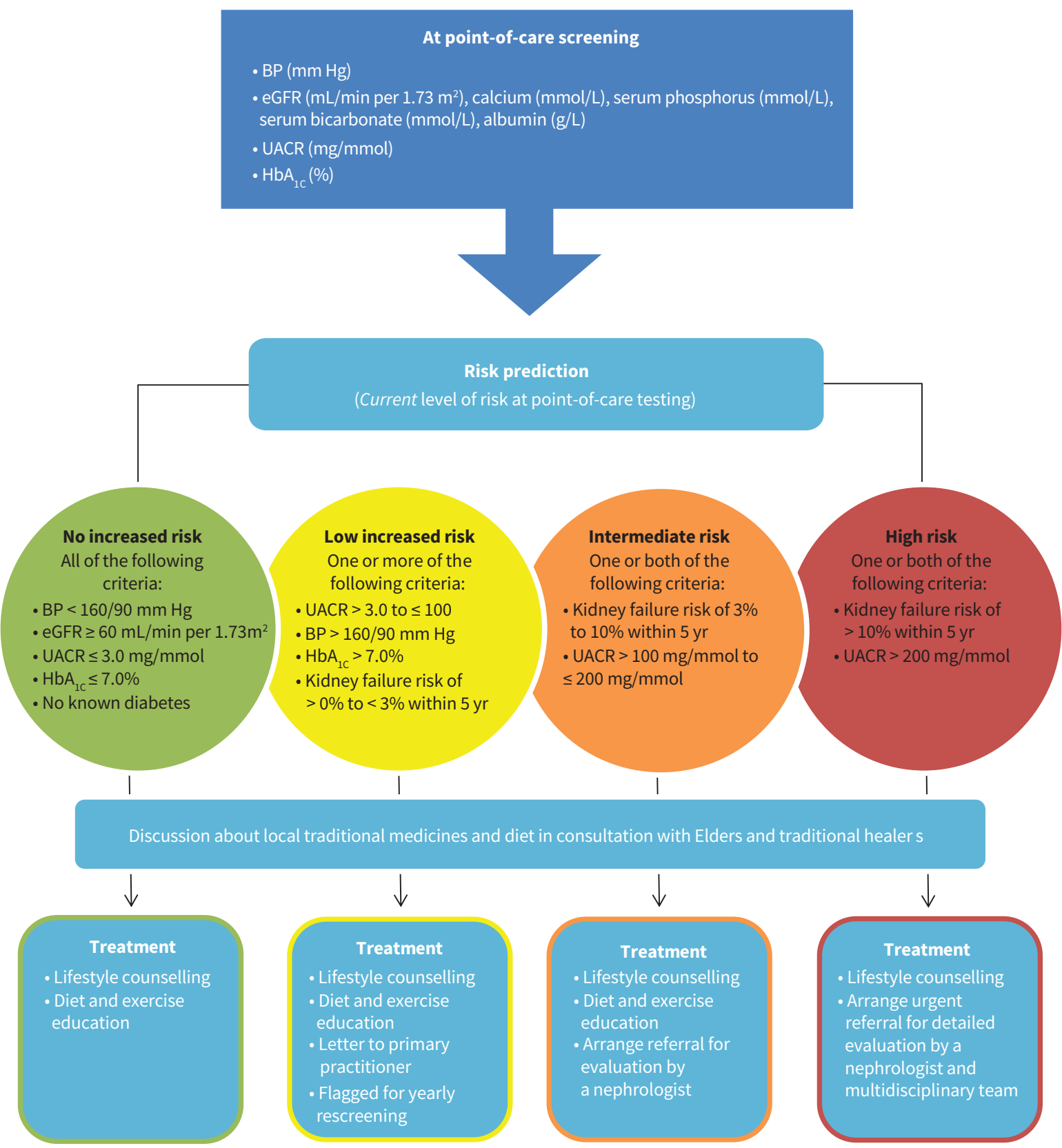

Figure 1: Criteria for determining kidney failure risk. Note: $\mathrm{BP}=$ blood pressure, eGFR = estimated glomerular filtration rate, $\mathrm{HbA}_{\mathrm{lc}}=$ glycosylated hemoglobin, UACR = urine albumin to creatinine ratio.

We identified visits to nephrologists and primary care physicians in outpatient settings 18 months pre- and postscreening using codes associated with physicians' practice, according to previously validated case definitions established by the Manitoba Centre for Health Policy. ${ }^{25,26}$

\section{Matched control comparison}

To assess whether the change in frequencies of each outcome measure observed over time in the intervention group significantly differed from a group of individuals who did not receive the intervention, we assembled a 1:1 matched comparison group consisting of adults living in rural and remote Indigenous communities that were not part of FINISHED, using propensity score methods. We assigned a pseudo-screening date to individuals in the comparison group based on the frequency distributions of time from start to end of the screening period. ${ }^{27,28}$ We matched individuals screened by FINISHED 1 to 1 with individuals in the comparison group, without replacement, within a caliper distance of $20 \%$ of the pooled standard deviation of the logit of the propensity score. ${ }^{29}$ Variables used in the propensity score model included age, sex, rural or remote dwelling location, and comorbidities. We calculated standardized differences for all characteristics to assess balance between groups and considered a greater than $10 \%$ difference between groups after matching to be unbalanced. 


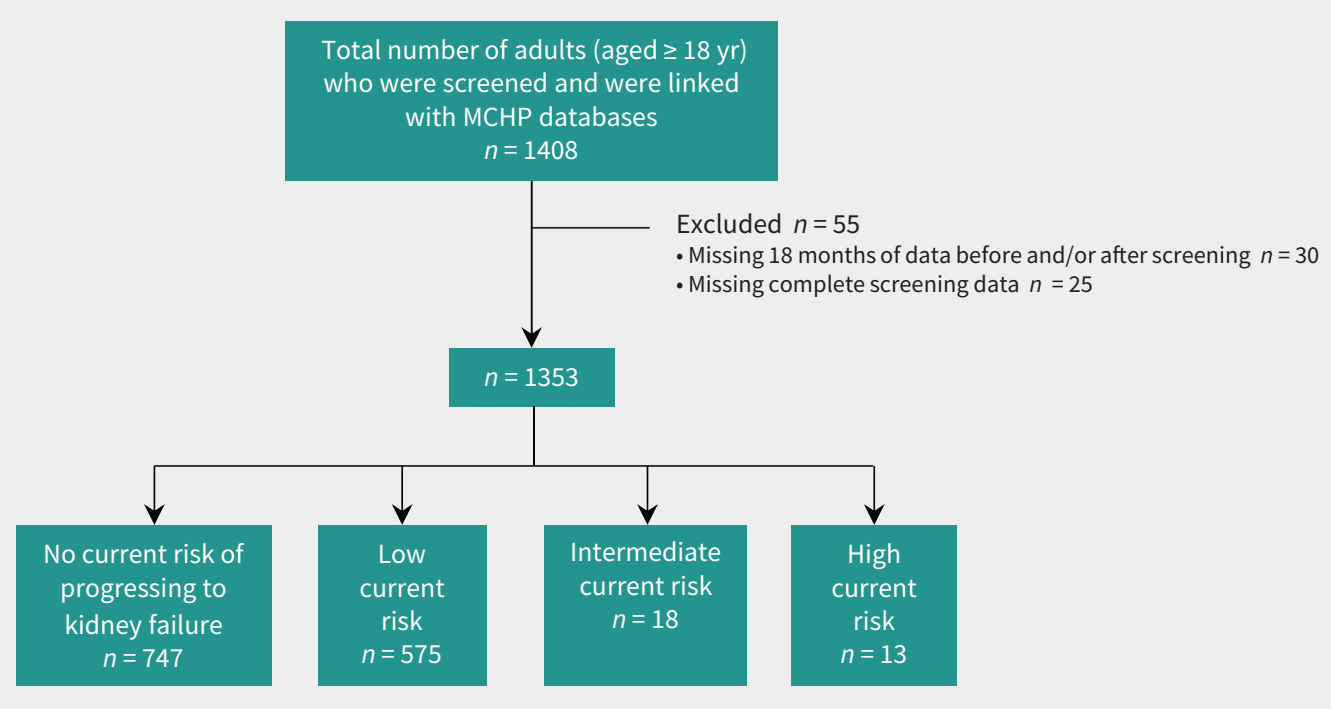

Figure 2: Study flow diagram. Note: MCHP = Manitoba Centre for Health Policy.

Table 1: Adult FINISHED participants with "no risk" of kidney failure versus those with "at least some risk" (low, intermediate or high risk), at time of their point-of-care screening*

\begin{tabular}{|c|c|c|c|}
\hline Characteristic & $\underset{n=1353}{\text { All† }}$ & $\begin{array}{c}\text { No risk†‡ } \\
n=747\end{array}$ & $\begin{array}{l}\text { At least some risk } † \ddagger \\
\qquad n=606\end{array}$ \\
\hline Mean age $\pm S D$, yr & $45.9 \pm 14.4$ & $42.5 \pm 14.7$ & $50.2 \pm 12.7$ \\
\hline Female sex, no. (\%) & $822(60.8)$ & $453(60.6)$ & $369(60.9)$ \\
\hline \multicolumn{4}{|l|}{ Dwelling location, no. (\%) } \\
\hline Rural & $744(55.0)$ & $464(62.1)$ & $280(46.2)$ \\
\hline Remote & $609(45.0)$ & $283(37.9)$ & $326(53.8)$ \\
\hline $\begin{array}{l}\text { Mean systolic blood pressure } \pm \text { SD, } \\
\mathrm{mm} \mathrm{Hg}\end{array}$ & $121.6 \pm 16.4$ & $117 \pm 12.9$ & $126.9 \pm 18.6$ \\
\hline $\begin{array}{l}\text { Mean diastolic blood pressure } \pm \text { SD, } \\
\mathrm{mm} \mathrm{Hg}\end{array}$ & $75.6 \pm 10.5$ & $73.8 \pm 8.6$ & $77.1 \pm 12.2$ \\
\hline Elevated blood pressure§, no. (\%) & $212(15.7)$ & $39(5.2)$ & $173(28.6)$ \\
\hline Mean eGFR $\pm S D, m L / m i n$ per $1.73 \mathrm{~m}^{2}$ & $106.2 \pm 21.4$ & $108.9 \pm 18.7$ & $103.0 \pm 24.0$ \\
\hline $\begin{array}{l}\text { No. (\%) with an eGFR }<60 \mathrm{~mL} / \mathrm{min} \text { per } \\
1.73 \mathrm{~m}^{2}\end{array}$ & supp. & supp. & $37(6.1)$ \\
\hline Median UACR (IQR), mg/mmol & $1.5(0.6$ to 3.1$)$ & $0.8(0.5$ to 1.6$)$ & 3.7 (1.6 to 11.3$)$ \\
\hline $\mathrm{HbA}_{1 \mathrm{c}}>7.0 \%$, no. $(\%)$ & $398(29.4)$ & - & $398(65.7)$ \\
\hline \multicolumn{4}{|l|}{ Kidney failure risk $\ddagger$, no. (\%) } \\
\hline No risk & $747(55.2)$ & $747(100)$ & - \\
\hline Low risk & $575(42.5)$ & - & $575(94.9)$ \\
\hline Intermediate risk & $18(1.3)$ & - & $18(3.0)$ \\
\hline High risk & $13(1.0)$ & - & $13(2.2)$ \\
\hline \multicolumn{4}{|c|}{ 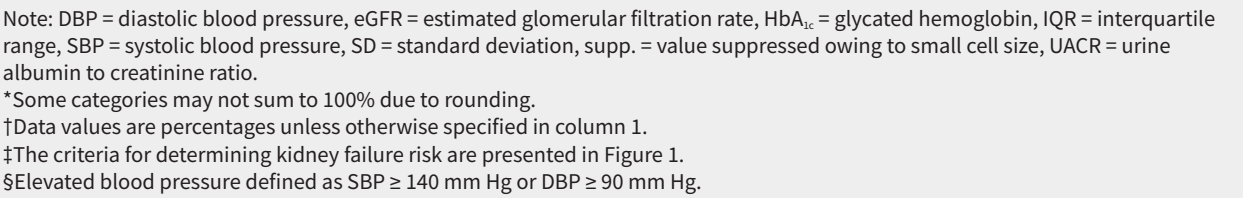 } \\
\hline
\end{tabular}


Table 2: Proportion of individuals receiving appropriate laboratory testing, disease-modifying medications and follow-up with primary care and nephrology physicians, before and after point-of-care screening, stratified by risk level

\begin{tabular}{|c|c|c|c|c|c|c|c|}
\hline \multirow[b]{2}{*}{ Characteristic } & \multicolumn{3}{|c|}{$\begin{array}{l}\text { No risk at screening } \\
\qquad n=747\end{array}$} & \multicolumn{3}{|c|}{$\begin{array}{l}\text { At least some risk at screening } \\
\qquad n=606\end{array}$} & \multirow{2}{*}{$\begin{array}{c}\text { Difference in } \\
\% \text { change } \\
(95 \% \mathrm{Cl}) \dagger\end{array}$} \\
\hline & $\begin{array}{l}\% \text { before } \\
\text { screening }\end{array}$ & $\begin{array}{l}\% \text { after } \\
\text { screening }\end{array}$ & $\begin{array}{l}\% \text { difference } \\
(95 \% \mathrm{CI})^{\star}\end{array}$ & $\begin{array}{l}\% \text { before } \\
\text { screening }\end{array}$ & $\begin{array}{l}\% \text { after } \\
\text { screening }\end{array}$ & $\begin{array}{l}\% \text { difference } \\
(95 \% \mathrm{Cl})^{*}\end{array}$ & \\
\hline $\begin{array}{l}\text { Comprehensive testing } \\
\text { (eGFR + UACR or UPCR } \\
\text { testing) }\end{array}$ & 16.3 & 25.2 & $\begin{array}{c}8.8 \\
(4.8 \text { to } 12.9)\end{array}$ & 49.3 & 66.3 & $\begin{array}{c}17.0 \\
(11.5 \text { to } 22.5)\end{array}$ & $\begin{array}{c}8.2 \\
(1.5 \text { to } 14.9)\end{array}$ \\
\hline eGFR testing & 38.4 & 53.2 & $\begin{array}{c}14.7 \\
(9.7 \text { to } 19.2)\end{array}$ & 64.7 & 82.0 & $\begin{array}{c}17.3 \\
(12.4 \text { to } 22.2)\end{array}$ & $\begin{array}{c}2.6 \\
(-4.5 \text { to } 9.7)\end{array}$ \\
\hline UACR or UPCR testing & 24.1 & 27.4 & $3.4(-1.1$ to 7.8$)$ & 61.6 & 69.5 & $\begin{array}{c}7.9 \\
\text { (2.6 to } 13.3)\end{array}$ & $\begin{array}{c}4.6 \\
(-2.3 \text { to } 11.5)\end{array}$ \\
\hline $\mathrm{HbA}_{1 \mathrm{c}} \ddagger$ & - & - & - & 85.7 & 89.4 & $\begin{array}{c}3.7 \\
(-0.5 \text { to } 8.0)\end{array}$ & - \\
\hline \multicolumn{8}{|c|}{ Disease-modifying medications } \\
\hline Statin & 14.3 & 14.7 & $\begin{array}{c}0.4 \\
(-3.2 \text { to } 4.0)\end{array}$ & 51.3 & 55.0 & $\begin{array}{c}3.6 \\
(-2.0 \text { to } 9.3)\end{array}$ & $\begin{array}{c}3.2 \\
(-3.2 \text { to } 9.7)\end{array}$ \\
\hline $\begin{array}{l}\text { Antihyperglycemic } \\
\text { medications } \ddagger\end{array}$ & - & - & - & 90.5 & 94.9 & $\begin{array}{c}4.4 \\
(1.0 \text { to } 7.8)\end{array}$ & - \\
\hline ACE inhibitor or ARB§ & - & - & - & 65.3 & 67.5 & $\begin{array}{c}2.2 \\
(-3.4 \text { to } 7.8)\end{array}$ & - \\
\hline $\begin{array}{l}\text { Any other } \\
\text { antihypertensive }\end{array}$ & 14.3 & 15.8 & $\begin{array}{c}1.5 \\
(-2.2 \text { to } 5.1)\end{array}$ & 36.8 & 41.4 & $\begin{array}{c}4.6 \\
(-0.9 \text { to } 10.1)\end{array}$ & $\begin{array}{c}3.2 \\
(-3.2 \text { to } 9.5)\end{array}$ \\
\hline Primary care visits & 85.3 & 84.7 & $\begin{array}{c}-0.5 \\
(-4.2 \text { to } 3.1)\end{array}$ & 94.2 & 93.7 & $\begin{array}{l}-0.5 \\
(-3.2 \text { to } 2.2)\end{array}$ & $\begin{array}{c}0 \\
(-4.7 \text { to } 4.7)\end{array}$ \\
\hline Nephrology visits & supp. & supp. & - & 2.5 & 8.4 & $\begin{array}{c}5.9 \\
(3.4-8.5)\end{array}$ & - \\
\hline \multicolumn{8}{|c|}{ 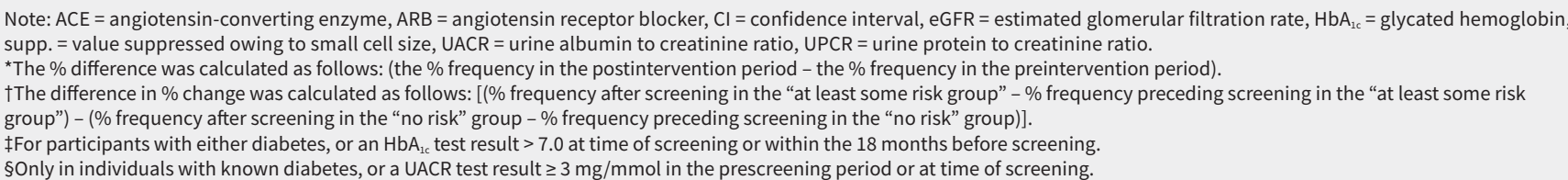 } \\
\hline
\end{tabular}

\section{Statistical analyses}

Descriptive statistics are expressed as mean \pm standard deviation for symmetrically distributed variables; median and interquartile ranges for skewed variables; and percentages for categorical variables. We compared frequencies of laboratory testing, medication prescriptions, and visits to primary care and nephrology in the 18 months before the screening date versus the frequencies observed in the 18 months after screening. The index date for all analyses was the date of screening. To evaluate whether the change in the frequency of outcomes between time periods differed between groups in each of the analyses (no risk v. some risk; rural dwelling location v. remote in people with some risk; 1:1 matched control group v. intervention group), we applied a difference-in-differences approach, which helps to control for secular trends over time. We constructed generalized estimating equation models where the changes over time were compared using the interaction between group (e.g., intervention and control) and time (pre- and post-). ${ }^{30,31}$ We performed analyses using SAS version 9.4.

\section{Ethics approval}

The FINISHED screening program was approved by the University of Manitoba Health Research Ethics Board and by the Tribal Council leaders, Chief and council leaders in each of the communities.

\section{Results}

\section{Intervention group}

In total, 1470 adults were screened (see screening rates in Appendix 1 , Supplementary Table 3). We were able to link 1408 individuals with administrative data, and 1353 had complete screening and administrative data available (Figure 2 shows the flow diagram); we identified 747 as having no risk of progressing to kidney failure at time of screening, and 606 as having at least some risk. Table 1 displays the demographic and screening characteristics of the population.

Table 2 presents the proportions of laboratory testing in the 18 months before and 18 months after the point-of-care screening. In the group of participants with at least some risk at screening, comprehensive testing improved by $17 \%$ (95\% confidence interval 
Table 3: Proportion of participants with "at least some risk" at screening of progressing to kidney failure who received appropriate laboratory testing, disease-modifying medications and follow-up with primary care and nephrology physicians, stratified by dwelling location

\begin{tabular}{|c|c|c|c|c|c|c|c|}
\hline \multirow[b]{3}{*}{ Characteristic } & \multicolumn{6}{|c|}{ At least some risk of kidney failure at screening } & \multirow{3}{*}{$\begin{array}{c}\text { Difference in \% } \\
\text { change } \\
(95 \% \mathrm{Cl}) \dagger\end{array}$} \\
\hline & \multicolumn{3}{|c|}{$\begin{array}{l}\text { Rural dwellers } \\
\qquad n=280\end{array}$} & \multicolumn{3}{|c|}{$\begin{array}{c}\text { Remote dwellers } \\
\quad n=326\end{array}$} & \\
\hline & $\begin{array}{l}\% \text { before } \\
\text { screening }\end{array}$ & $\begin{array}{l}\% \text { after } \\
\text { screening }\end{array}$ & $\begin{array}{c}\% \text { difference } \\
(95 \% \mathrm{Cl})^{*}\end{array}$ & $\begin{array}{l}\text { \% before } \\
\text { screening }\end{array}$ & $\begin{array}{l}\% \text { after } \\
\text { screening }\end{array}$ & $\begin{array}{c}\% \text { difference } \\
(95 \% \mathrm{CI})^{\star}\end{array}$ & \\
\hline $\begin{array}{l}\text { Comprehensive testing } \\
\text { (eGFR + UACR or UPCR } \\
\text { testing) }\end{array}$ & 26.8 & 55.7 & $\begin{array}{c}28.9 \\
\text { (21.1 to } 36.7)\end{array}$ & 68.7 & 75.5 & $\begin{array}{c}6.8 \\
(-0.1 \text { to } 13.6)\end{array}$ & $\begin{array}{c}-22.2 \\
(-32.5 \text { to }-11.8)\end{array}$ \\
\hline eGFR testing & 39.3 & 73.9 & $\begin{array}{c}34.6 \\
\text { (27.0 to } 42.3 \text { ) }\end{array}$ & 86.5 & 89.0 & $\begin{array}{c}2.5 \\
(-2.6 \text { to } 7.5)\end{array}$ & $\begin{array}{c}-32.2 \\
(-41.1 \text { to }-23.2)\end{array}$ \\
\hline UACR or UPCR testing & 53.2 & 61.4 & $\begin{array}{c}8.2 \\
(0.05 \text { to } 16.4)\end{array}$ & 68.7 & 76.4 & $\begin{array}{c}7.7 \\
\text { (0.8 to } 14.5)\end{array}$ & $\begin{array}{c}0.6 \\
(-11.1 \text { to } 10.0)\end{array}$ \\
\hline $\mathrm{HbA}_{1 c} \ddagger$ & 78.5 & 84.9 & $\begin{array}{c}6.3 \\
(-1.1 \text { to } 13.8)\end{array}$ & 91.6 & 93.2 & $\begin{array}{c}1.6 \\
(-3.1 \text { to } 6.3)\end{array}$ & $\begin{array}{c}-4.7 \\
(-13.2 \text { to } 3.8)\end{array}$ \\
\hline \multicolumn{8}{|c|}{ Disease-modifying medications } \\
\hline Statin & 50.4 & 51.8 & $\begin{array}{c}1.4 \\
(-6.9 \text { to } 9.7)\end{array}$ & 52.3 & 57.7 & $\begin{array}{c}5.5 \\
(-2.1 \text { to } 13.2)\end{array}$ & $\begin{array}{c}4.1 \\
(-7.2 \text { to } 15.3)\end{array}$ \\
\hline $\begin{array}{l}\text { Antihyperglycemic } \\
\text { medications } \ddagger\end{array}$ & 88.3 & 94.6 & $\begin{array}{c}6.3 \\
\text { (1.0 to } 11.7)\end{array}$ & 92.4 & 95.2 & $\begin{array}{c}2.8 \\
(-1.4 \text { to } 7.1)\end{array}$ & $\begin{array}{c}-4.5 \\
(-10.3 \text { to } 3.2)\end{array}$ \\
\hline ACE inhibitor or ARB§ & 63.4 & 64.2 & $\begin{array}{c}0.8 \\
(-7.7 \text { to } 9.4)\end{array}$ & 66.8 & 70.0 & $\begin{array}{c}3.3 \\
(-4.1 \text { to } 10.6)\end{array}$ & $\begin{array}{c}2.4 \\
(-8.8 \text { to } 13.7)\end{array}$ \\
\hline $\begin{array}{l}\text { Any other } \\
\text { antihypertensive }\end{array}$ & 35.4 & 40.0 & $\begin{array}{c}4.6 \\
(-3.4 \text { to } 12.7)\end{array}$ & 38.0 & 42.6 & $\begin{array}{c}4.6 \\
(-2.9 \text { to } 12.1)\end{array}$ & $\begin{array}{c}0.04 \\
(-11.1 \text { to } 11.0)\end{array}$ \\
\hline Primary care visits & 96.4 & 96.8 & $\begin{array}{c}0.4 \\
(-2.6 \text { to } 3.4)\end{array}$ & 92.3 & 91.1 & $\begin{array}{c}-1.2 \\
(-5.5 \text { to } 3.0)\end{array}$ & $\begin{array}{c}-1.7 \\
(-2.2 \text { to } 5.5)\end{array}$ \\
\hline Nephrology visits & supp. & 4.6 & - & 3.4 & 11.7 & $\begin{array}{c}8.3 \\
\text { (4.3 to } 12.3)\end{array}$ & - \\
\hline \multicolumn{8}{|c|}{ 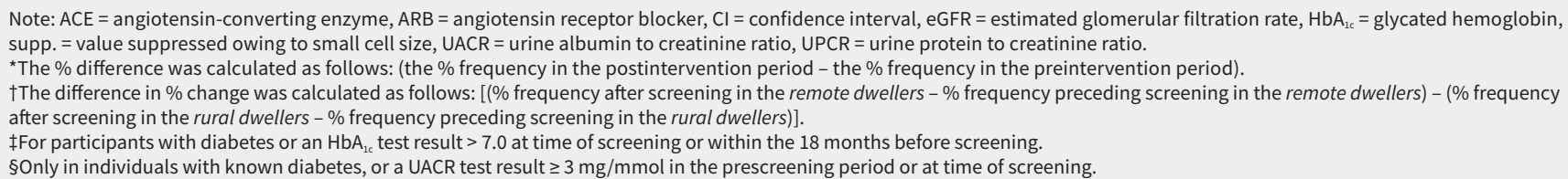 } \\
\hline
\end{tabular}

[CI] $11.5 \%$ to $22.5 \%)$ an increase that was $8.2 \%(95 \% \mathrm{Cl} 1.5$ to 14.9$)$ greater than for people not at risk. eGFR testing increased by $17.3 \%$ ( $95 \% \mathrm{Cl} 12.4$ to 22.2 ), and UACR or UPCR testing increased by $7.9 \%$ ( $95 \% \mathrm{Cl} 2.6$ to 13.3$)$. However, these improvements were not statistically different than for the people not at risk. For nephrology visits, in people with at least some risk at screening, visits significantly increased by $5.9 \%$ ( $95 \% \mathrm{Cl} 3.4$ to 8.5 ).

Table 3 displays the results for individuals with at least some risk of kidney failure at screening, stratified by dwelling location. Substantial increases for laboratory testing, including UACR or UPCR, occurred in both rural and remote groups, and eGFR and $\mathrm{HbA}_{1 \mathrm{c}}$ testing increased in the rural dwellers. The increase in comprehensive testing and eGFR testing in the rural group was statistically significantly higher than the increase in the remote group.

\section{Intervention group versus matched comparison group}

Appendix 1, Supplementary Table 4 presents demographic and comorbidity data on the intervention and comparison groups. The groups were balanced on age, sex, and comorbidities (the standardized differences were all less than 0.1). Table 4 shows data comparing outcomes of the 2 groups; versus the comparison group, the intervention group overall had a significantly greater change in comprehensive laboratory tests completed $15.0 \%$ [95\% $\mathrm{Cl} 0.1 \%$ to $9.8 \%]$ ), UACR or UPCR testing $(5.8 \%$ [95\% $\mathrm{Cl} 0.7 \%$ to $10.9 \%]), \mathrm{HbA}_{1 \mathrm{c}}(7.0 \%$ [95\% $\mathrm{Cl} 0.6 \%$ to $13.3 \%]$ ), antihyperglycemic medications (7.7\% [95\% $\mathrm{Cl} 2.7 \%$ to $12.6 \%])$ and nephrology visits (1.9\% [95\% Cl $0.3 \%$ to $3.4 \%]$ ). We did not observe any other statistically significant differences between groups with the remaining outcomes.

\section{Interpretation}

After point-of-care screening, we observed notable increases in laboratory testing of kidney function and urinary protein, prescriptions of disease-modifying medications, and visits to nephrology for individuals who had some risk of progressing to kidney failure at time of screening. Rural dwellers with at least some current risk had the greatest improvement in testing 
Table 4: Propensity-matched comparison of percent change between the screened group and the nonscreened comparison group*

\begin{tabular}{|c|c|c|c|c|c|c|c|}
\hline \multirow[b]{2}{*}{ Characteristic } & \multicolumn{3}{|c|}{$\begin{array}{c}\text { Comparison group } \\
\qquad n=1353\end{array}$} & \multicolumn{3}{|c|}{$\begin{array}{l}\text { Intervention group } \\
\qquad n=1353\end{array}$} & \multirow{2}{*}{$\begin{array}{l}\text { Difference in } \\
\% \text { change } \\
(95 \% \mathrm{Cl}) \ddagger\end{array}$} \\
\hline & $\begin{array}{l}\% \text { before } \\
\text { index date }\end{array}$ & $\begin{array}{c}\% \text { after } \\
\text { index date }\end{array}$ & $\begin{array}{c}\% \text { difference } \\
(95 \% \mathrm{Cl}) \dagger\end{array}$ & $\begin{array}{l}\% \text { before } \\
\text { index date }\end{array}$ & $\begin{array}{c}\% \text { after } \\
\text { index date }\end{array}$ & $\begin{array}{c}\% \text { difference } \\
(95 \% \mathrm{Cl}) \dagger\end{array}$ & \\
\hline $\begin{array}{l}\text { Comprehensive testing } \\
\text { (eGFR + UACR or UPCR } \\
\text { testing) }\end{array}$ & 19.8 & 27.4 & $\begin{array}{c}7.5 \\
\text { (4.4 to } 10.7 \text { ) }\end{array}$ & 31.1 & 43.6 & $\begin{array}{c}12.5 \\
\text { (8.9 to } 16.1)\end{array}$ & $\begin{array}{c}5.0 \\
\text { (0.1 to } 9.8)\end{array}$ \\
\hline eGFR testing & 33.6 & 52.0 & $\begin{array}{c}18.4 \\
\text { (14.7 to } 22.1)\end{array}$ & 50.2 & 66.1 & $\begin{array}{c}15.9 \\
(12.2 \text { to } 19.6)\end{array}$ & $\begin{array}{c}-2.5 \\
(-7.7 \text { to } 2.7)\end{array}$ \\
\hline UACR or UPCR testing & 31.4 & 31.0. & $\begin{array}{c}-0.4 \\
(-3.9 \text { to } 3.1)\end{array}$ & 40.9 & 46.3 & $\begin{array}{c}5.4 \\
(1.7 \text { to } 9.1)\end{array}$ & $\begin{array}{c}5.8 \\
\text { (0.7 to } 10.9)\end{array}$ \\
\hline $\mathrm{HbA}_{1 \mathrm{c}}$ testing $\S$ & 80.4 & 77.0 & $\begin{array}{c}-3.3 \\
(-8.4 \text { to } 1.7)\end{array}$ & 85.4 & 89.0 & $\begin{array}{c}3.6 \\
(-0.3 \text { to } 7.6)\end{array}$ & $\begin{array}{c}7.0 \\
\text { (0.6 to } 13.3 \text { ) }\end{array}$ \\
\hline \multicolumn{8}{|c|}{ Disease-modifying medications } \\
\hline Statin & 23.1 & 26.7 & $\begin{array}{c}3.6 \\
(0.4 \text { to } 7.9)\end{array}$ & 30.9 & 32.7 & $\begin{array}{c}1.9 \\
(-1.7 \text { to } 5.4)\end{array}$ & $\begin{array}{c}-1.8 \\
(-6.6 \text { to } 3.0)\end{array}$ \\
\hline $\begin{array}{l}\text { Antihyperglycemic } \\
\text { medications§ }\end{array}$ & 91.9 & 88.0 & $\begin{array}{c}-3.1 \\
(-6.8 \text { to } 0.5)\end{array}$ & 88.6 & 93.1 & $\begin{array}{c}4.5 \\
\text { (1.1 to } 7.9)\end{array}$ & $\begin{array}{c}7.7 \\
\text { (2.7 to } 12.6)\end{array}$ \\
\hline ACE inhibitor or ARB 9 & 67.6 & 69.1 & $\begin{array}{c}1.5 \\
(-4.1 \text { to } 7.2)\end{array}$ & 63.3 & 65.8 & $\begin{array}{c}2.4 \\
(-2.7 \text { to } 7.6)\end{array}$ & $\begin{array}{c}0.9 \\
(-6.8 \text { to } 8.6)\end{array}$ \\
\hline $\begin{array}{l}\text { Any other } \\
\text { antihypertensive }\end{array}$ & 27.0 & 28.2 & $\begin{array}{c}1.2 \\
(-2.2 \text { to } 4.6)\end{array}$ & 24.4 & 27.3 & $\begin{array}{c}2.9 \\
(-0.4 \text { to } 6.2)\end{array}$ & $\begin{array}{c}1.7 \\
(-3.0 \text { to } 6.4)\end{array}$ \\
\hline Primary care visits & 80.5 & 76.9 & $\begin{array}{c}-3.6 \\
(-6.7 \text { to }-0.5)\end{array}$ & 89.2 & 88.8 & $\begin{array}{c}-0.5 \\
(-2.9 \text { to } 1.8)\end{array}$ & $\begin{array}{c}3.1 \\
(-0.08 \text { to } 7.0)\end{array}$ \\
\hline Nephrology visits & 1.6 & 2.4 & $\begin{array}{c}0.7 \\
(-0.3 \text { to } 1.8)\end{array}$ & 1.3 & 3.8 & $\begin{array}{c}2.6 \\
\text { (1.4 to } 3.8)\end{array}$ & $\begin{array}{c}1.9 \\
\text { (0.3 to } 3.4)\end{array}$ \\
\hline \multicolumn{8}{|c|}{ 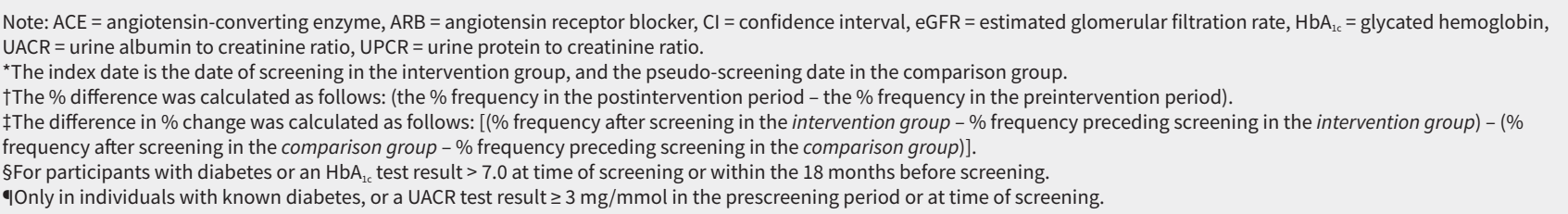 } \\
\hline
\end{tabular}

rates, whereas we saw only modest improvements among remote dwellers. This was in part because of low testing rates before screening in rural communities. Additionally, compared with a control group of individuals from unscreened Indigenous communities, screening was associated with substantially greater improvements in comprehensive testing, UACR or UPCR testing, use of antihyperglycemic medications and nephrology visits. Large-scale improvements in public health interventions take time to implement, scale and spread. We observed a larger than expected baseline level of testing and treatment compared with other studies from the general population. ${ }^{32}$ We view this as positive in that the message regarding proper kidney disease screening had an effect on these primary care systems by a relatively small number of care providers and bodes well for the implementation of earlier, targeted interventions more widely available now, such as SGLT-2 inhibitors. These findings provide evidence to support the use of robust point-of-care testing programs that improve the identification of chronic kidney disease and risk factors, which could help ensure individuals receive appropriate preventive care moving forward.

In population-based Canadian cohort studies of people with diabetes or chronic kidney disease or both, Indigenous individuals were less likely than non-Indigenous individuals to receive tests monitoring $\mathrm{HbA}_{1 c}$ and kidney function, ${ }^{7,33}$ less likely to visit a nephrologist ${ }^{34,35}$ or primary care physician, and had less continuity of care. ${ }^{34}$ In a study assessing the management of type 2 diabetes and hypertension in select Canadian Indigenous communities, most individuals did not meet glycemic, lipid and blood pressure targets. Among people with diabetes, $55.1 \%$ were prescribed a statin, $72.1 \%$ an ACE inhibitor or an ARB, and $84.2 \%$ of people with hypertension were on an antihypertensive medication. ${ }^{36}$ In a study assessing care indicators in Indigenous communities in northwestern Ontario, $28.3 \%$ of people had at least 1 eGFR test, and $15.2 \%$ at least 1 UACR test. Among people with recognized chronic kidney disease, $52.7 \%$ received a statin and $33.3 \%$ received an ACE inhibitor or ARB. ${ }^{37}$ 


\section{Limitations}

Although we were able to capture all prescriptions and physician visits, and our relatively short follow-up time allowed us to assess immediate impact, our length of follow-up was not sufficient to examine long-term outcomes such as mortality, dialysis initiation, kidney function, rates of home dialysis or cardiovascular outcomes. ${ }^{38,39}$ In Manitoba, as much as $30 \%$ of laboratory testing is performed by non-DSM laboratories, which were not captured by the available data, therefore potentially leading to an underestimation of the frequency of laboratory testing. However, because the invention and comparison communities are located in regions that do not have non-DSM laboratory locations nearby, we expect that this number would be small. We believe that there were few exclusions due to incomplete screening data and missing administrative $(<4 \%)$ data and they did not substantially bias the results.

Additionally, in our propensity score model, we were not able to control for factors such as lifestyle, and other social determinants of health such as housing, food security or intergenerational trauma. Furthermore, given that substantial advertising was conducted during the FINISHED study, we may have inadvertently reached physicians and individuals in nonscreened communities, which may have had an impact on increased rates of testing observed in the comparison group. Lastly, we recruited participants in the program using convenience sampling, in turn potentially introducing a self-selection bias.

\section{Conclusion}

Indigenous communities located in low-resource intensity areas often lack dedicated resources for chronic disease management and prevention. Point-of-care screening programs directed by multidisciplinary teams can opportunistically identify individuals at risk of kidney failure, and provide results to participants in real time with counselling and referrals to nephrology and specialist services to "close the loop" of care, helping to ensure follow-up care to mitigate risk of progression. The FINISHED screening program provided the pilot evidence needed to develop and launch the Kidney Check program: a permanent chronic kidney disease surveillance system in rural and remote Indigenous communities across Canada, working toward introducing a new paradigm of care to decrease the burden of chronic kidney disease and kidney failure with early detection, education and treatment. ${ }^{40-43}$

\section{References}

1. Gao S, Manns BJ, Culleton BF, et al. Prevalence of chronic kidney disease and survival among Aboriginal people. J Am Soc Nephrol 2007;18:2953-9.

2. Zacharias JM, Young TK, Riediger ND, et al. Prevalence, risk factors and awareness of albuminuria on a Canadian First Nation: a community-based screening study. BMC Public Health 2012;12:290.

3. Martens PJ, Martin BD, O'Neil JD, et al. Diabetes and adverse outcomes in a First Nations population: associations with healthcare access, and socioeconomic and geographical factors. Can J Diabetes 2007;31:223-32.

4. Riediger ND, Lukianchuk V, Bruce SG. Incident diabetes, hypertension and dyslipidemia in a Manitoba First Nation. Int J Circumpolar Health 2015;74:27712.

5. Jiang Y, Osgood N, Lim H-J, et al. Differential mortality and the excess burden of end-stage renal disease among First Nations people with diabetes mellitus: a competing-risks analysis. CMAJ 2014;186:103-9.

6. Dyck RF, Jiang Y, Osgood ND. The long-term risks of end stage renal disease and mortality among first nations and non-first nations people with youthonset diabetes. Can J Diabetes 2014;38:237-43.

7. Nash DM, Dirk JS, McArthur E, et al. Kidney disease and care among First Nations people with diabetes in Ontario: a population-based cohort study. CMAJ Open 2019;7:E706-12.
8. Thomas DA, Huang A, McCarron MCE, et al. A retrospective study of chronic kidney disease burden in Saskatchewan's First Nations people. Can J Kidney Health Dis 2018;5. doi: 10.1177/2054358118799689.

9. End-stage renal disease among Aboriginal peoples in Canada: treatment and outcomes. Ottawa: Canadian Institute for Health Information; 2013.

10. Guo C, Tam T, Bo Y, et al. Habitual physical activity, renal function and chronic kidney disease: a cohort study of nearly 200000 adults. Br J Sports Med 2020;54:1225-30.

11. Ricardo AC, Anderson CA, Yang W, et al. Healthy lifestyle and risk of kidney disease progression, atherosclerotic events, and death in CKD: findings from the Chronic Renal Insufficiency Cohort (CRIC) study. Am J Kidney Dis 2015;65:412-24.

12. Lv J, Ehteshami P, Sarnak MJ, et al. Effects of intensive blood pressure lowering on the progression of chronic kidney disease: a systematic review and metaanalysis. CMAJ 2013;185:949-57.

13. Xie X, Liu Y, Perkovic V, et al. Renin-angiotensin system inhibitors and kidney and cardiovascular outcomes in patients with CKD: a Bayesian network metaanalysis of randomized clinical trials. Am J Kidney Dis 2016;67:728-41.

14. Zelniker TA, Wiviott SD, Raz I, et al. SGLT2 inhibitors for primary and secondary prevention of cardiovascular and renal outcomes in type 2 diabetes: a systematic review and meta-analysis of cardiovascular outcome trials. Lancet 2019;393:31-9.

15. Komenda P, Ferguson TW, Macdonald K, et al. Cost-effectiveness of primary screening for CKD: a systematic review. Am J Kidney Dis 2014;63:789-97.

16. Ferguson TW, Tangri N, Tan Z, et al. Screening for chronic kidney disease in Canadian indigenous peoples is cost-effective. Kidney Int 2017;92:192-200.

17. Hoerger TJ, Wittenborn JS, Zhuo X, et al. Cost-effectiveness of screening for microalbuminuria among African Americans. J Am Soc Nephrol 2012;23:2035-41.

18. Shephard MDS. Cultural and clinical effectiveness of the "QAAMS" point-of-care testing model for diabetes management in Australian Aboriginal medical services. Clin Biochem Rev 2006;27:161-70.

19. Lavallee B, Chartrand C, McLeod L, et al. Mass screening for chronic kidney disease in rural and remote Canadian First Nations people: methodology and demographic characteristics. Can J Kidney Health Dis 2015;2:9.

20. Komenda P, Lavallee B, Ferguson TW, et al. The prevalence of CKD in rural Canadian Indigenous peoples: results from the First Nations Community Based Screening to Improve Kidney Health and Prevent Dialysis (FINISHED) screen, triage, and treat program. Am J Kidney Dis 2016;68:582-90.

21. Harasemiw O, Milks S, Oakley L, et al. Remote dwelling location is a risk factor for CKD among Indigenous Canadians. Kidney Int Rep 2018;3:825-32.

22. Manitoba Centre for Health Policy. Winnipeg: University of Manitoba. Available: https://umanitoba.ca/faculties/health_sciences/medicine/units/chs/departmental _units/mchp/ (accessed 2021 Mar. 29).

23. Tangri N, Grams ME, Levey AS, et al.; CKD Prognosis Consortium. Multinational assessment of accuracy of equations for predicting risk of kidney failure. JAMA 2016;315:164-74.

24. Tangri N, Stevens L, Griffith J, et al. A predictive model for progression of chronic kidney disease to kidney failure. JAMA 2011;305:1553-9.

25. Concept: ambulatory visits - concept description. Winnipeg: Manitoba Centre for Health Policy, Community Health Sciences, Max Rady College of Medicine, Rady Faculty of Health Sciences, University of Manitoba; updated 2020 Feb. 18. Available: http://mchp-appserv.cpe.umanitoba.ca/viewConcept.php?printer=Y\& conceptID=1069 (accessed 2019 Oct. 28).

26. Term: Nephrologist visits - concept description. Winnipeg: Manitoba Centre for Health Policy, Community Health Sciences, Max Rady College of Medicine, Rady Faculty of Health Sciences, University of Manitoba; updated 2015 Dec. 14 Available: http://mchp-appserv.cpe.umanitoba.ca/viewDefinition.php?printer $=$ Y\&definitionID=104796 (accessed 2020 Apr. 20).

27. Harvey R, Drzayich Jankus D, Mosley D. UnitedHealthcare. Random assignment of proxy event dates to unexposed individuals in observational studies: an automated technique using SAS. MWSUG 2012: Paper PH02-2012. Midwest SAS Users Group; 2012. Available: www.mwsug.org/proceedings/2012/PH/MWSUG-2012-PH02.pdf (accessed 2021 Mar. 29).

28. Rocque GB, Pisu M, Jackson BE, et al. Resource use and medicare costs during lay navigation for geriatric patients with cancer. JAMA Oncol 2017;3:817-25.

29. Austin PC. Optimal caliper widths for propensity-score matching when estimating differences in means and differences in proportions in observational studies. Pharm Stat 2011;10:150-61.

30. Dimick JB, Ryan AM. Methods for evaluating changes in health care policy: The difference-in-differences approach. JAMA 2014;312:2401-2.

31. Stuart EA, Huskamp HA, Duckworth K, et al. Using propensity scores in differencein-differences models to estimate the effects of a policy change. Health Serv Outcomes Res Methodol 2014;14:166-82.

32. Bello AK, Ronksley PE, Tangri N, et al. Quality of chronic kidney disease management in Canadian primary care. JAMA Netw. Open 2019;2:e1910704.

33. Deved V, Jette N, Quan H, et al.; Alberta Kidney Disease Network. Quality of care for First Nations and non-First Nations people with diabetes. Clin J Am Soc Nephrol 2013;8:1188-94. 
34. Shah BR, Slater M, Frymire E, et al. Use of the health care system by Ontario First Nations people with diabetes: a population-based study. CMAJ Open 2020;8:E313-8.

35. Gao S, Manns B, Culleton B, et al.; Alberta Kidney Disease Network. Access to health care among status Aboriginal people with chronic kidney disease. CMAJ 2008;179:1007-12.

36. Harris SB, Naqshbandi M, Bhattacharyya O, et al.; CIRCLE Study Group. Major gaps in diabetes clinical care among Canada's First Nations: results of the CIRCLE study. Diabetes Res Clin Pract 2011;92:272-9.

37. Kelly L, Matsumoto C-L, Schreiber Y, et al. Prevalence of chronic kidney disease and cardiovascular comorbidities in adults in First Nations communities in northwest Ontario: a retrospective observational study. CMAJ Open 2019;7:E568-72.

38. Toyama T, Neuen BL, Jun M, et al. Effect of SGLT2 inhibitors on cardiovascular, renal and safety outcomes in patients with type 2 diabetes mellitus and chronic kidney disease: a systematic review and meta-analysis. Diabetes Obes Metab 2019;21:1237-50.
39. Neuen BL, Young T, Heerspink HJL, et al. SGLT2 inhibitors for the prevention of kidney failure in patients with type 2 diabetes: a systematic review and metaanalysis. Lancet Diabetes Endocrinol 2019;7:845-54.

40. Levin A, Adams E, Barrett BJ, et al. Canadians Seeking Solutions and Innovations to Overcome Chronic Kidney Disease (Can-SOLVE CKD): form and function. Can J Kidney Health Dis 2018;5. doi: 10.1177/2054358117749530.

41. Curtis S, Collister D, Martin H, et al. The Kidney Check program - championing patient-centered, culturally safe, preventive kidney care in Canada's rural and remote Indigenous communities. EJIFCC 2021;32:61-8

42. Kidney check. Can-SOLVE CKD Kidney Check. Available: www.cansolveckd. com/research/kidney-check/ (accessed 2021 Mar. 29).

43. Curtis $\mathrm{S}$, Sokoro $\mathrm{A}$, Martin $\mathrm{H}$, et al. A comprehensive quality assurance platform in Canada for national point of care chronic kidney disease screening: the Kidney Check Program. Kidney Int Rep 2020;6:513-7.
Competing interests: Oksana Harasemiw reports receiving personal fees from Tricida Inc., outside the submitted work. Thomas Ferguson reports receiving personal fees from ClinPredict, Quanta Dialysis Technologies Ltd. and Strategic Health Resources, outside the submitted work. Claudio Rigatto reports receiving grants from Sanofi and AstraZeneca Canada, outside the submitted work. Navdeep Tangri reports receiving grants and personal fees from AstraZeneca, Janssen, BI-Lilly and Otsuka; grants, personal fees and stock options from Tricida; personal fees and stock options from Pulsedata, Mesentech and Renibus; and is an owner of ClinPredict, outside the submitted work. Dr. Tangri also has a patent pending for a microfluidic device for point-of-care detection of urine albumin. Paul Komenda reports receiving grants from the Health Services Integration Fund (Health Canada) and from the Canadian Institutes of Health Research, during the conduct of the study. No other competing interests were declared.

This article has been peer reviewed.

Affiliations: Chronic Disease Innovation Centre (Harasemiw, Ferguson, Rigatto, Tangri, Komenda), Seven Oaks General Hospital; Max Rady Department of Internal Medicine (Harasemiw, Ferguson, Rigatto, Tangri, Komenda), University of Manitoba; First Nations Health and Social Secretariat of Manitoba (Lavallee, McLeod); Manitoba Keewatinowi Okimakanak Inc. (Lavallee, Chartrand); Department of Pediatrics and Child Health (Dart), University of Manitoba; Children's Hospital Research Institute of Manitoba (Dart), Winnipeg, Man.

Contributors: Oksana Harasemiw, Thomas Ferguson, Navdeep Tangri, Claudio Rigatto and Paul Komenda contributed to the conception and design of the work. All of the authors contributed to the acquisition of data. Oksana Harasemiw and Thomas Ferguson contributed to the analysis of data. All of the authors contributed to interpreting the data. All of the authors drafted the manuscript, revised it critically for important intellectual content, gave final approval of the version to be published and agreed to be accountable for all aspects of the work.

Content licence: This is an Open Access article distributed in accordance with the terms of the Creative Commons Attribution (CC BY-NC-ND 4.0) licence, which permits use, distribution and reproduction in any medium, provided that the original publication is properly cited, the use is noncommercial (i.e., research or educational use), and no modifications or adaptations are made. See: https://creativecommons.org/licenses/by-nc-nd/4.0/

Funding: Funding for this study was obtained through a Health Services Integration Fund grant from Health Canada. The funder had no role in the study design; collection, analysis, and interpretation of data; writing the report; nor in the decision to submit this manuscript.

Data sharing: Data are available from the Manitoba Centre for Health Policy, University of Manitoba, for researchers who meet the criteria for access to confidential data. Data included are housed at Manitoba Health, Diagnostic Services of Manitoba, and the First Nations Health and Social Secretariat of Manitoba. All data used in our analysis are publicly available and held by the Government of Manitoba or contracted agencies (e.g., laboratory services). Access to this data requires approval by the University of
Manitoba Health Research Ethics Board, the Government of Manitoba's Health Privacy Information Committee, and the First Nations Health and Social Secretariat of Manitoba. Legal restrictions prevent the use of these data without approval from each of the individual trustees. All of these data are provided in de-identified format and linked through a remote access server maintained by the Manitoba Centre for Health Policy (http:// umanitoba.ca/faculties/health_sciences/medicine/units/chs/departmental _units/mchp/). Email address: info@cpe.umanitoba.ca. Specific data sets used in this project include: (a) Shared Health Diagnostic Services of Manitoba (laboratory tests), Diagnostic Services Manitoba, 1502-155 Carlton Street, Winnipeg, Manitoba, R3C 3H8, 1-204-926-8005. Information available at: http://umanitoba.ca/faculties/health_sciences/medicine /units/chs/departmental_units/mchp/resources/repository/descriptions .html?ds=DSM. (b) Hospital Discharge Abstracts (hospitalizations) Health Information Privacy Committee, Manitoba Health, Seniors and Active Living, 4044-300 Carlton Street, Winnipeg, Manitoba, R3B 3M9. Information available at: http://umanitoba.ca/faculties/health_sciences/medicine/ units/chs/departmental_units/mchp/resources/repository/descriptions. html?ds=Hospital. (c) Manitoba Health Insurance Registry (registration coverage periods, demographics), Health Information Privacy Committee, Manitoba Health, Seniors and Active Living, 4044-300 Carlton Street, Winnipeg, Manitoba, R3B 3M9. Information available at: http://umanitoba.ca/ faculties/health_sciences/medicine/units/chs/departmental_units/mchp/ resources/repository/descriptions.html?ds=Insurance. (d) Manitoba Health Medical Services (physician claims/billings), Health Information Privacy Committee, Manitoba Health, Seniors and Active Living, 4044-300 Carlton Street, Winnipeg, Manitoba, R3B 3M9. Information available at: http://umanitoba.ca/faculties/health_sciences/medicine/units/chs/ departmental_units/mchp/resources/repository/descriptions.html?ds= MedicalClaims. (e) Drug Program Information Network - DPIN (pharmacy dispensing), Health Information Privacy Committee, Manitoba Health, Seniors and Active Living, 4044-300 Carlton Street, Winnipeg, Manitoba, R3B 3M9. Information available at: http://umanitoba.ca/faculties/health_ sciences/medicine/units/chs/departmental_units/mchp/resources/ repository/descriptions.html?ds=DPIN. (f) The FINISHED Screening Database, First Nations Health and Social Secretariat of Manitoba, 275 Portage Avenue, Suite 600, 6th Floor The Kensington Building, Winnipeg, MB R3B 2B3.

Acknowledgements: The authors acknowledge the Manitoba Centre for Health Policy for use of data contained in the Manitoba Population Research Data Repository under project \#2018/2019-50. The results and conclusions are those of the authors and no official endorsement by the Manitoba Centre for Health Policy, Manitoba Health, Diagnostic Services of Manitoba, or other data providers is intended or should be inferred. Data used in this study are from the Manitoba Population Research Data Repository housed at the Manitoba Centre for Health Policy, University of Manitoba, and were derived from data provided by Manitoba Health, The First Nations Health and Social Secretariat, and Shared Health.

Accepted: Mar. 25, 2021

Correspondence to: Paul Komenda, pkomenda@sogh.mb.ca 